\title{
FLOWERING BIOLOGY AND NECTARY STRUCTURE OF Melissa officinalis L.
}

\author{
Mirosława Chwil \\ Department of Botany, University of Life Sciences in Lublin, 20-950 Lublin, Akademicka 15, \\ Poland, e-mail: miroslawa.chwil@up.lublin.pl
}

Received: 7.08.2009

\section{Abstract}

The present study on lemon balm (Melissa officinalis L.) covered flowering biology, monitoring of pollinating insects and floral nectary structure. The micromorphology of epidermal cells of the nectary was investigated using scanning electron microscopy. The nectariferous tissues were observed using light microscopy based on semi-thin sections.

Lemon balm flowered from the second decade of June until September. Buds opened from early morning hours until noon. Flowers lived for 24 hours, on the average. Their primary pollinator was the honey bee. The beginning of nectar secretion was found to be at the bud swell stage. The automorphic nectary forms a disc with four protrusions at the base of the nectary. Three smaller ones and one larger than the other ones were distinguished among them. No stomata were found on the lower protuberances, whereas on the highest part anomocytic stomata were present, the number of which was 15 . The stomata exhibited different development stages and they were situated above other epidermal cells. In their outline, they were ellipsoidally shaped $(18 \times 23 \mu \mathrm{m})$ and they had average-sized cuticular ledges. They produced a smooth cuticle and wax granules. In cross section, the nectary tissues were composed of a singlelayered epidermis and 9-11 layers of the nectary parenchyma. Their thickness was $198 \mu \mathrm{m}$. In longitudinal section, the height of the nectary was within a range of $354-404 \mu \mathrm{m}$. The epidermal cells produced thin outer cell walls. Some of them were completely filled with strongly stained cytoplasm, whereas others showed a high degree of vacuolisation. But the nectary parenchyma cells were marked by poorly stained cytoplasm, a large nucleus and vacuolisation of varying degree.

Key words: Melissa officinalis, blooming, visiting insects, nectary, micromorphology, stomata, anatomy

\section{INTRODUCTION}

Lemon balm (Melissa officinalis) is native to southern Europe, Asia Minor and the Caucasus ( $\mathrm{S} \mathrm{zw}$ e y k ow s cy, 2003). In Poland in the 16th century, lemon balm used to be planted in monastery gardens (G ór a and Li s, 2007). Melissa officinalis releases lemon-scented essential oil which contains active substances, among others: citronellal, citronellol, geranial, neral and linalol (V a v e r k o v a et al. 2002; Gór a and Lis, 2007; Adenie etal. 2008; Cos ge et al. 2009). Thanks to these compounds, lemon balm is classified as an important medicinal, spice and cosmetic plant; it also exhibits sedative, antiseptic and antihistaminic activity (Nemeth and Szekely, 2000; Muntean and Marian, 2005; B ahtiyarc a and Coşge, 2006; Adenie et al. 2008). Due to aromatic values, valuable pharmacological components as well as the ornamental and apicultural value of its flowers, lemon balm is often grown in vegetable and herb gardens (S q u ire, 2007; S i k or a, 2008). In literature, honey yield of lemon balm is estimated to be $32-150 \mathrm{~kg} / \mathrm{ha}$ (D e m i a n o w i c z, 1953; B a naszak, 1993; Muntean and Marian, 2005; Kołtowski, 2006).

Nectar secretion onto the surface of the nectary occurs through stomata in flowers of Lamiaceae plants. The nectaries in Lamiaceae form, at the base of the nectary, a disc which, depending on the taxon, differs in its size, symmetry, shape and number of protrusions (Dafni et al. 1988; Weryszko-Chmielew ska, 2000; Weryszko-Chmielewska and Chwil, 2002; Chwil, 2007). Based on these traits, Weryszko-Chmielewska (2000) distinguished three groups of floral nectaries in plants of the family Lamiaceae. However, P e ta n id o u et al. (2000) report that the nectary structure in this family is determined to a great degree by phylogenetic and climatic conditions.

The aim of the present study was to determine flowering biology, groups of pollinating insects and nectary structure in the flowers of Melissa officinalis. 


\section{MATERIALS AND METHODS}

The study of lemon balm (Melissa officinalis L.) flowers was carried out in the years 2006 - 2007 in the Botanical Garden of the Maria Curie-Skłodowska University in Lublin. Flower lifetime and the daily rate of flower opening were estimated as well as flower visitation by insects was monitored.

For microscopic analysis of the nectaries, portions of flowers at full bloom stage were sampled. The structure of the nectaries was investigated using stereoscopic, light and scanning electron microscopy. The micromorphology of epidermal cells of the nectary was analysed under a BS-300 Tesla scanning electron microscope. The plant material for SEM analysis was fixed in $4 \%$ glutaraldehyde and $0.1 \mathrm{M}$ phosphate buffer with a $\mathrm{pH}$ of 7.2. After being treated with $1 \%$ osmium tetroxide and dehydrated in acetone series, the samples were critical-point dried and then coated with gold using a sputter coater.

The nectariferous tissues were observed under a light microscope based on semi-thin sections. After postfixing, the plant material was dehydrated in alcohol series and embedded in Spurr's low viscosity embedding resin. $0.5-0.7 \mu \mathrm{m}$ sections were cut on a Reichert Ultracut $\mathrm{S}$ ultramicrotome. Then, they were stained with $1 \%$ toluidine blue with $1 \%$ azur II in a $1 \%$ aqueous solution of sodium tetraborate. Observations and photographs were made with a Nikon YS100 microscope.

\section{RESULTS}

Flowering and flower visitation by insects

In the climatic conditions of Lublin, lemon balm flowered from the second decade of June until September. In the upper part of its stems, it produced white flowers, clustered in one-sided pseudo-whorls with 3 -6 flowers in each. Numerous hairs were growing on the surface of the perianth elements (Figs 3A, B).

Buds opened from early morning hours until noon. The process of flower opening from the bursting bud until the generative elements reached maturity lasted about 30 minutes. The studied flowers lived for 24 hours, on the average. Following senescence, the corolla abscised, whereas the sepals remained on the plants and performed a protective function for the fruits.

The greatest intensity of blooming was observed in morning hours. The number of open flowers until $9^{00}$ accounted for $66 \%$ of all flowers which opened during the day. But between $9^{00}$ and $11^{00}$, one half fewer flowers bloomed. In afternoon hours, from $13^{00}$ to $15^{00}$, new single flowers opened only sporadically (Fig. 1).

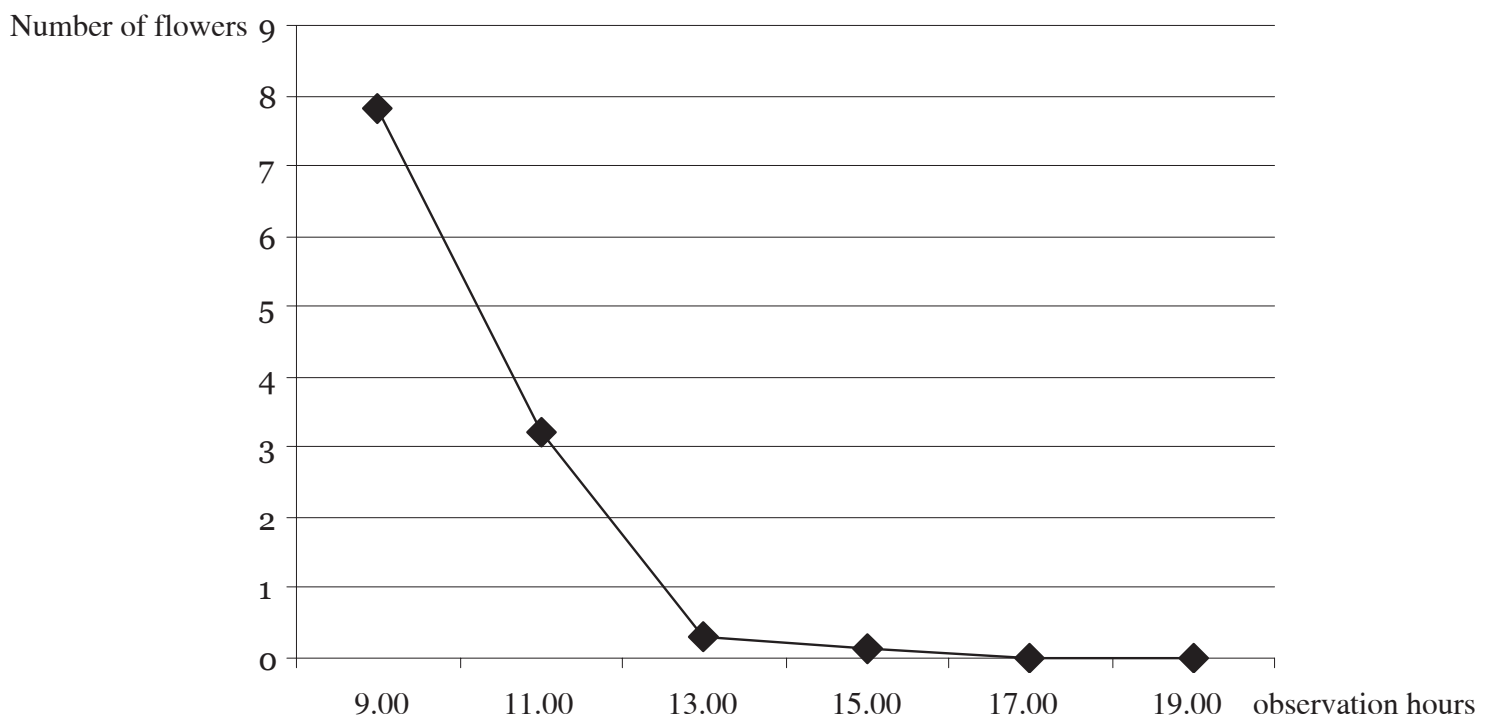

Fig. 1. The daily rate of flower opening of Melissa officinalis.

The lemon balm flowers were visited by several groups of insects, among which the honey bee was the primary pollinator. The largest number of pollinating insects was observed between $9^{00}$ and $12^{00}$. The percentage proportions of honey bees, solitary bees and bumblebees in the pollination of lemon balm flowers were, respectively: $45 \%, 18 \%$ and $13 \%$. Other pollinating insects (dipterans and butterflies) accounted for $24 \%$ of the pollinators observed (Fig. 2). 

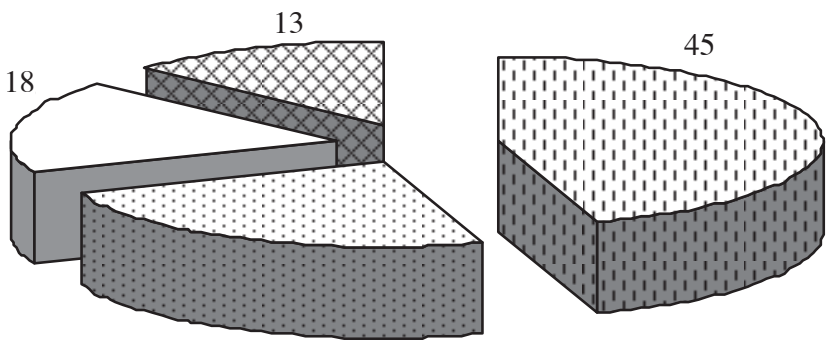

24

四 honey bees $\quad$ other pollinating insects $\square$ solitary bees $\quad$ bumblebees

Fig. 2. Percentage proportions of insects in the pollination of Melissa officinalis flowers.

\section{Nectary micromorphology}

The beginning of nectar secretion in the lemon balm flowers was found to be at the bud swell stage. Nectar is produced by the automorphic nectary located at the base of the four-parted ovary (Figs 3C - F). The nectariferous tissue of lemon balm forms an asymmetric disc with four protrusions which enter between the particular parts of the four-parted ovary. Among these protrusions, three smaller ones and one larger than the other ones were distinguished. No stomata were found on the lower protuberances (Figs 3D - F). In these regions, the epidermal cells produced a smooth cuticle with slight folding (Figs 3E, G). The height of particular parts of the nectary ranged between 354 and 404 $\mu \mathrm{m}$. The convex part with stomata was elevated above the other portions of the gland up to a height of approx. $70 \mu \mathrm{m}$. The diameter of the nectary in its widest part was within a range of $657-687 \mu \mathrm{m}$, reaching an average value of $677 \mu \mathrm{m}$.

In the highest part of the nectary, clusters of anomocytic stomata were found, which were responsible for nectar secretion (Fig. 3F, H). The average number of stomata on a single protrusion was 15 . The stomatal cells were arranged irregularly and they demonstrated different development stages. There occurred both closed stomata, with the swollen cuticle visible over the pore, and open stomata with different pore apertures (Figs 3H, 4A - I).
The stomata, surrounded by $5-7$ cells, were situated above other epidermal cells. In their outline, they were ellipsoidally shaped $(18 \times 23 \mu \mathrm{m})$ and they had average-sized cuticular ledges. They produced a smooth cuticle, which was slightly folded on other epidermal cells of the nectary (Figs 4A - I). On the nectary's protrusion with the stomatal region, there occurred wax granules, at places forming larger irregular clusters (Figs 4A, B, D - F).

\section{Nectary anatomy}

In cross section, the nectary tissues were composed of a single-layered epidermis and 9-11 layers of the nectary parenchyma. These cells formed a compact arrangement. Their thickness was within a range of $182-236 \mu \mathrm{m}$, reaching an average value of 198 $\mu \mathrm{m}$. The epidermal cells of the nectary were isodiametrically shaped. They produced thin outer cell walls. Among them, cells filled with strongly stained cytoplasm were visible, or highly vacuolised brighter ones (Figs 5A, C).

The walls of the nectary parenchyma cells were thin. The cells of this layer were marked by poorly stained granular cytoplasm, a large nucleus and vacuolisation of varying degree (Figs $5 \mathrm{~A}-\mathrm{C}$ ). The parenchyma cells of the receptacle formed a looser arrangement; they were larger than the nectary parenchyma cells. Around a large vacuole, they produced a thin parietal strand of cytoplasm (Figs 5A, B, D). 

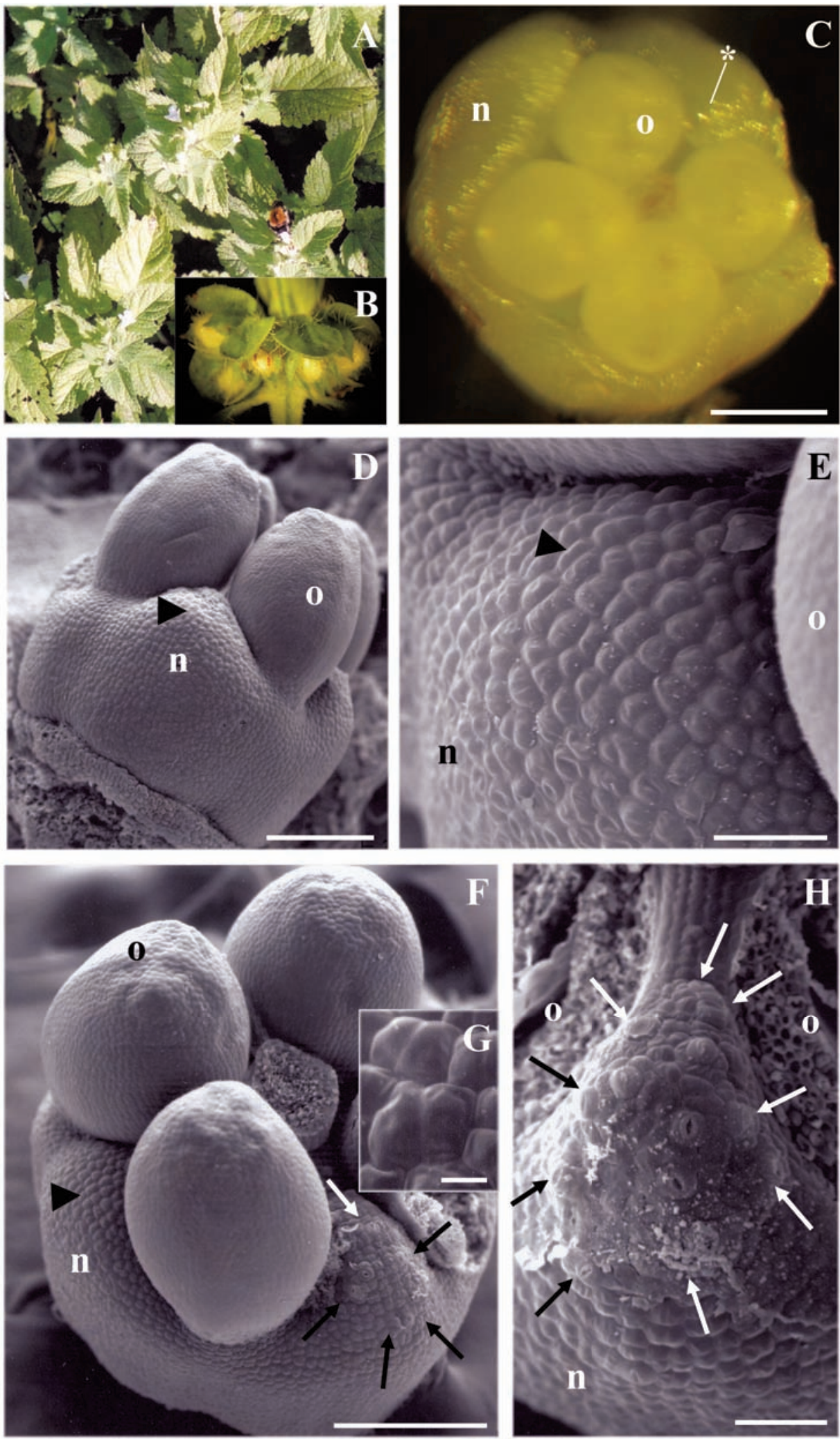

Figs 3. Flowering plants (A, B) and portions of the nectary (n) with the ovary (o) of Melissa officinalis.

$\mathrm{C}$ - nectar droplet visible on the surface of the nectary (asterisk).

D - H - nectary's protrusions without stomata (arrowhead) and with the stomatal region (arrows).

$\mathrm{C}, \mathrm{D}, \mathrm{F}-$ bars $=200 \mu \mathrm{m} ; \mathrm{G}-$ bar $=10 \mu \mathrm{m} ; \mathrm{H}, \mathrm{E}-$ bars $=50 \mu \mathrm{m}$. 

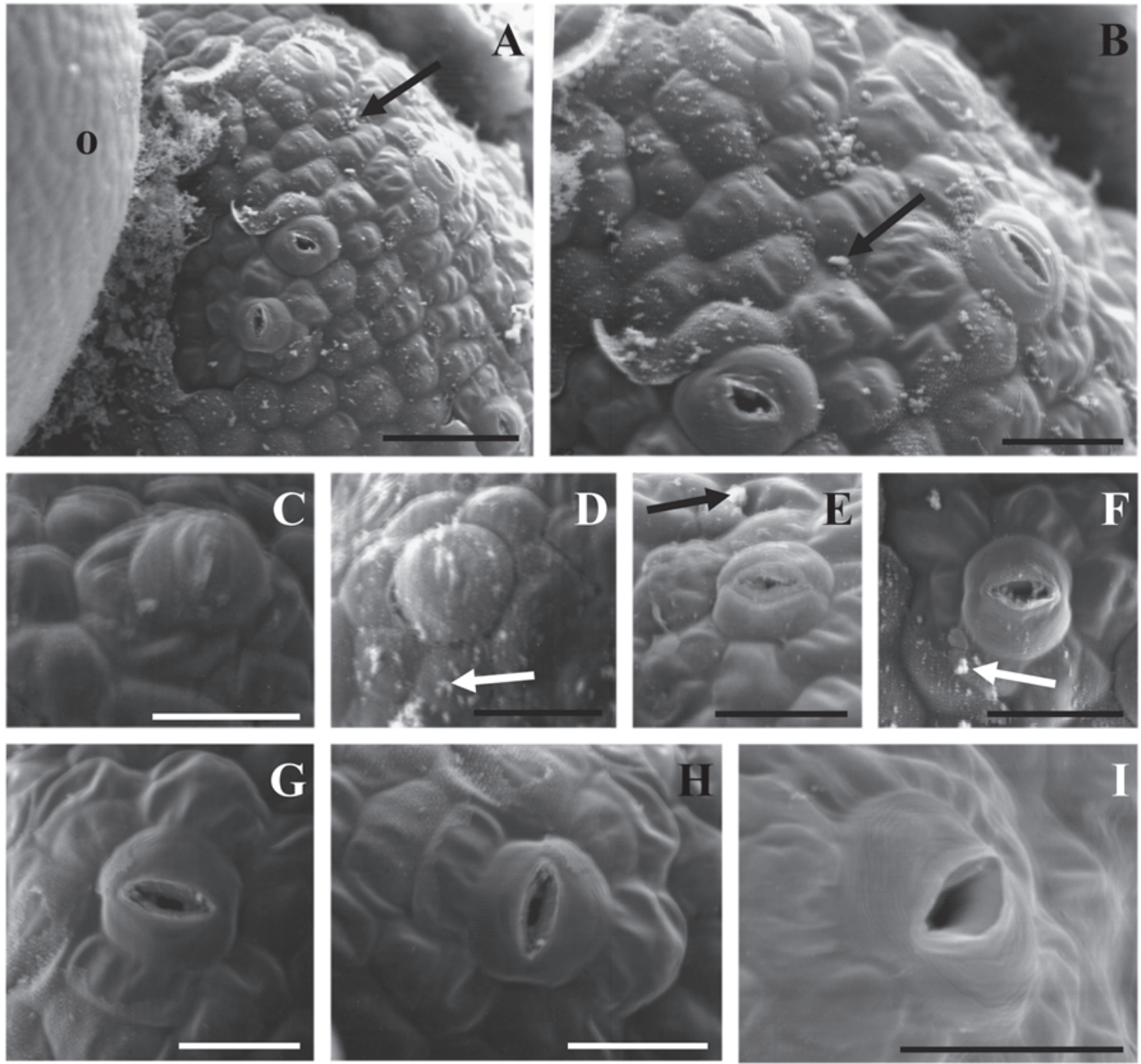

Fig 4. Portions of the nectary epidermis with the stomatal region in Melissa officinalis flowers.

A - from the side of the ovary (o). Visible wax granules, at places forming larger structures (arrow). Bar $=50 \mu \mathrm{m}$.

$\mathrm{B}-$ in the apical part.

C - I - different development stages of stomata, visible smooth cuticle on the surface of stomatal cells and folds on other epidermal cells. $\mathrm{B}-\mathrm{I}-$ bars $=20 \mu \mathrm{m}$. 

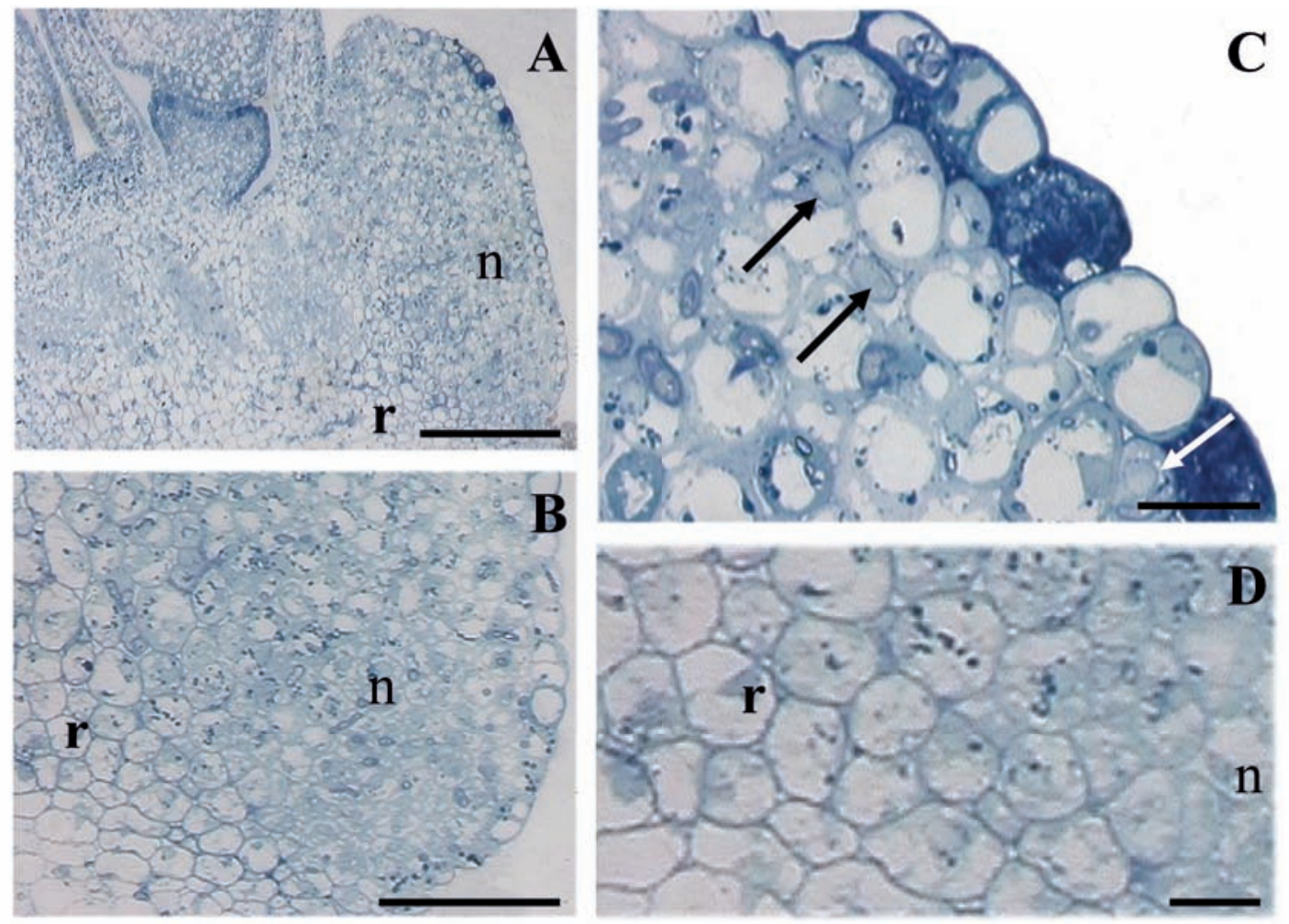

Fig 5. Portions of the nectary (n) and receptacle (r) of Melissa officinalis.

A - longitudinal section of the lower part of the flower with the nectary. A - bar $=100 \mu \mathrm{m}$.

$\mathrm{B}-$ portion of the nectary whose cells have smaller sizes than the receptacle cells. Bar $=100 \mu \mathrm{m}$.

C - epidermal cells with strongly stained cytoplasm and highly vacuolised brighter cells with thin cell walls; large nuclei (arrows) and vacuolisation of varying degree are visible in the nectary parenchyma cells. C - bar $=20 \mu \mathrm{m}$.

$\mathrm{D}$ - cells of the nectary undergoing destruction at the end of nectar secretion and distinctly outlined cells of the receptacle. Bar $=20 \mu \mathrm{m}$.

\section{DISCUSSION}

The studied lemon balm flowered for over two months. On the average, flowers lived for 24 hours. They bloomed most intensely in morning hours. Bees and bumblebees were the primary pollinators of the studied lemon balm, described in literature (B o ż e k, 2000). Literature reports show that flowers of numerous plant species of the family Lamiaceae are pollinated mainly by bees (D a f n i, 1991; P e tan id o u and Vok ou, 1993).

This is also confirmed by studies on flowers of several Ocimum species, in which Apis mellifera visits accounted for $50-98 \%$ (Male rbo-S ouza et al. 2000; C h w i 1, 2007). In the studies of D a f n i et al. (1988), among 9 plant species of the family Lamiaceae, most frequent visits of bees were found in the flowers of Rosmarinus and Coridothymus capitatus. In explaining the pollinator-flower interaction, the authors divided the investigated taxa into 3 groups which differed in the sugar composition of nectar. The flowers of Melissa and
Rosmarinus, in whose nectar the amount of hexoses was equal to sucrose, were included in the first group; in the second group hexoses were predominant (Coridothymus, Salvia judaica and Stachys), whereas in the third one the largest amount of sucrose was found (Phlomis, Salvia fruticosa and Satureja).

The nectary in the investigated flowers of lemon balm forms, at the base of the ovary, an asymmetric disc with four protrusions with a height of 354 $-404 \mu \mathrm{m}$ and a diameter of $677 \mu \mathrm{m}$. It differs compared to the nectaries of other species of the family Lamiaceae described in literature. It is higher than the nectary gland of Origanum and Mentha, but lower than that in Nepeta, Hyssopus and Ocimum (Weryszko-Chmielewska, 2000; Chwil, 2007; Mačukanović-Jocić et al. 2007). On the other hand, its diameter was smaller by 50 up to $70 \%$ than the diameter of the nectaries of Ocimum (Chwil, 2003, 2007; Macukanovic-Jocic et al. 2007). According to Mačukanović-J ocić et al. (2007), cells of the nectary in basil flowers in- 
creased their diameter during ontogeny. Other authors report that the nectary size in the flowers of Lamiaceae is positively correlated with nectar secretion, but not with its quality. Larger diameter nectaries are found in Lamiaceae flowers with a wide corolla and they develop large, open pores, whereas in deep flowers no such correlation has been demonstrated ( $\mathrm{D}$ a f $\mathrm{n}$ i et al. 1988; P e t a n id ou et al. 2000).

The stomata in the epidermis of the nectary of lemon balm exhibited different development stages. This suggests the possibility of regulating the pore aperture during nectar secretion. Petanidou et al. (2000) report that the process of pore opening in the nectaries of other plant species of the family Lamiaceae decreases at the time of anthesis, and at the same time it affects the nectar production rate and sugar concentration in nectar.

In the stomatal region of the nectary of the lemon balm flowers observed, 15 stomata were found on the average. It is known from literature data that the number of developed stomata on a protrusion of the nectariferous tissue in flowers of different taxa of the family Lamiaceae is variable. Their lowest number has been found in the epidermis of the nectaries of the genera Nepeta $(4-6)$ and Mentha $(7-$ $8)$, whereas higher stoma density has been observed in Ocimum (4 - 19), Hyssopus $(17-18)$ and Origanum (15 - 18) (W e r y s z k o-Ch mi e lew s ka, 2000; Chwil, 2007; M a čukanović-Jocić et al. 2007).

Ellipsoidal $(18 \times 23 \mu \mathrm{m})$ modified stomata in the nectary epidermis of lemon balm belonged to the anomocytic type. Their shape and size as well as their position are similar to those of diacytic stomata in leaf epidermis of this taxon described in an earlier paper (Chwil 2006). The location of stomata above other epidermal cells of the nectary is also confirmed by the studies of Dafni et al. (1988) relating to the flowers of Melissa officinalis, Coridothymus capitatus and Salvia thymbra.

The epidermal cells of the nectary of lemon balm produced a smooth or slightly folded cuticle as well as wax granules.

In cross section, the nectary tissues in the investigated Melissa officinalis flowers were composed of a single-layered epidermis and 9-11 layers of the nectary parenchyma. Their thickness was $198 \mu \mathrm{m}$, on the average. A similar number of cell layers (10) was found in the nectaries of Ocimum (M a č u k a n o v i ć Jocić et al. 2007).

\section{REFERENCES}

Adenie J., Piri K., Omid K., 2008. Essential Oil Component in Flower of Lemon Balm (Melissa officinalis L.). Am. J. Biochem. Biotech. 4 (3): 277-278.
Bahtiyarca B. R., Coşge B., 2006. The essential oil of lemon balm (Melissa officinalis L.), its components and using fields. J. of Fac. of Agric. OMU 21: 116-121.

B a n a s z a k J., 1993. Ekologia pszczół. PWN, Warszawa.

Bożek M., 2000. Flower pollinating insects of 32 species from Lamiaceae family. Pszczeln. Zesz. Nauk. 2: 293-303.

Chwil M., 2003. Biologia kwitnienia i nektarowanie bazylii (Ocimum basilicum cv. Genovese). / Flowering biology and nectar secretion of basil (Ocimum basilicum cv. Genovese). Ann. Univ. Mariae Curie-Skłodowska, sect. EEE, Hortic. 13: 118-121.

Chwil M., 2006. The micromophology of the epidermis surface of Melissa officinalis L. leaves. Materials of the International Scientific Conference. 15-20 october, Sukhum, Abkhazia: 6-7.

Chwil M., 2007. Flowering pattern, the structure of nectary surface and nectar secretion in two varieties of Ocimum basilicum L. Acta Agrobot. 60 (1): 55-65.

Cosge B., Ipek A., Gurbuz B., 2009. GC/MS analysis of herbage essential ol from lemon balms (Melissa officinalis L.) grown in Turkey. J. Appl. Biol. Sci. 3 (2): 136-139.

D a f n i A., 1991. Advertisement flower longevity, reward and nectar protection in Labiatae. Acta Hort. 288: 340-346.

Dafni A., Lensky Y., Fahn A., 1988. Flower and nectar characteristics of nine species of Labiatae and their influence on honeybee visits. J. apic. Res. 27 (2): 103114.

Demianowicz Z., 1953. Rośliny miododajne. PWRiL, Warszawa.

Gór a J., Lis A., 2007. Najcenniejsze olejki eteryczne. Wydaw. Uniwersytetu Mikołaja Kopernika, Toruń.

Kołtowski Z., 2006. Wielki atlas roślin miododajnych. Przedsiębiorstwo Wydawnicze Rzeczpospolita S.A, Warszawa.

Mačukanović-Jocić M. P. Rancic D. V., Stevanovic Z. P. D., 2007. Flora nectaries of basil (Ocimum basilicum): Morphology, anatomy and possible mode of secretion. South Afr. J. Bot. 73 (4): 636-641.

Malerbo-Souza D. T., Mota M. O. S., NogueiraCouto R. H., Souza J. C., 2000. Insects associated to the inflorescences of basil (Ocimum basilicum L.). Rev. Brasil. Plant. Med. 2 (2): 27-30.

Muntean L. S., Marian O., 2005. Melissa officinalis L. an important medicinal and aromatic plant. Hameiul si Plantele Medicinale. 13 (1/2): 207-212.

Nemeth E., Szekely G., 2000. Floral biology of medicinal plants II. Lamiaceae species. Int. J. Hort. Sci. 6: 137-140.

Petanidou T., Vokou D., 1993. Pollination ecology of Labiatae in a phryganic (East Mediterranean) ecosystem. Am. J. Bot. 80: 892-899.

Petanidou V., Goethals V., Smets E., 2000. Nectary structure of Labiatae in relation to their nectar secretion 
and characteristics in a Mediterranean shrub community. Does flowering time matter? Plant Syst. Evol. 225: 103-118.

Sikora E., 2008. Ogród ziołowy. Wydawnictwo Działkowiec, Warszawa.

Squire D., 2007. Ogród ziół. Projektowanie, zakładanie, udoskonalanie i pielęgnacja ogrodów ziołowych. Wydawnictwo. „Arkady”, Warszawa.

Szweykowscy A. i J., 2003. Słownik botaniczny. Państwowe Wydawnictwo Wiedza Powszechna, Warszawa.

Vaverková Š., Hollá M., Tekel J., Habán M., Vozár I., 2002. Qualitative properties of Melissa officinalis L. during ontogenetic development. Herba Polonica, 48 (4): 289-294.

Weryszko-Chmielewska E., 2000. Ecological features of flowers including nectary structure of chosen species from Lamiaceae family. Pszczel. Zesz. Nauk. 2: 223-232.

Weryszko-Chmielewska E., Chwil M., 2002. Blooming and nectar secretion of Nepeta grandiflora Bieb. under the condition of load excess. J. Apic. Sci. 46 (1): 59-65.

\section{Biologia kwitnienia i budowa nektarnika Melissa officinalis L.}

\section{Streszczenie}

Przeprowadzone badania melisy lekarskiej ( $M e$ lissa officinalis L.) obejmowały biologię kwitnienia, monitoring owadów zapylających i strukturę nektarnika kwiatowego. Mikromorfologię komórek epidermy nektarnika analizowano w skaningowym mikroskopie elektronowym. Tkanki nektarnikowe obserwowano w mikroskopie świetlnym w oparciu o preparaty półcienkie.

Melisa lekarska kwitła od drugiej dekady czerwca do września. Pąki rozwijały się od wczesnych godzin rannych do południa. Kwiaty żyły średnio dobę. Ich głównym zapylaczem była pszczoła miodna. Początek sekrecji nektaru stwierdzono w fazie nabrzmiałego pąka. Automorficzny nektarnik tworzy przy nasadzie zalążni dysk z czterema wzniesieniami. Wśród nich wyróżniono trzy mniejsze i jedno większe od pozostałych. Na niższych uwypukleniach brak było aparatów szparkowych, zaś na najwyższej części obecne były skupienia anomocytycznych aparatów szparkowych, których liczba wynosiła 15. Aparaty szparkowe wykazywały zróżnicowane fazy rozwoju i były usytuowane powyżej innych komórek epidermy. W zarysie miały kształt elipsoidalny $(18$ x $23 \mu \mathrm{m})$ i średniej wielkości listwy kutykularne. Na ich powierzchni obserwowano gładką kutykulę i granulki wosku. Tkanki nektarnika na przekroju poprzecznym obejmowały jednowarstwową epidermę i 9 - 11 warstw parenchymy nektarnikowej. Ich miąższość wynosiła $198 \mu$ m. Natomiast wysokość nektarnika na przekroju podłużnym wahała się w granicach $354-404 \mu \mathrm{m}$. Komórki epidermy tworzyły cienkie zewnętrzne ściany komórkowe. Niektóre były całkowicie wypełnione silnie zabarwioną cytoplazmą, inne wykazywały duży stopień wakuolizacji. Natomiast komórki parenchymy nektarnikowej wyróżniały się słabo zabarwioną cytoplazmą, dużym jądrem komórkowym i zróżnicowanym stopniem wakuolizacji. 